\title{
Dose-response study to evaluate dicamba tolerance in selected wild tomato germplasm
}

Rouzbeh Zangoueinejad $^{\text {a,b }}$; Mohammad Taghi Alebrahim ${ }^{\text {b; }}$ Edicarlos B. Castro ${ }^{\text {a }}$;

Shandrea Stallworth ${ }^{\mathrm{a}}$; Ziming Yue ${ }^{\mathrm{a}}$; Richard G. Snyder ${ }^{\mathrm{a}}$; Te Ming Tseng, ${ }^{\mathrm{a}, *}$

${ }^{a}$ Department of Plant and Soil Sciences, Mississippi State University, Box 9555, Mississippi

State, MS, 39762, USA;

${ }^{b}$ Department of Plant Production and Genetic, Faculty of Agricultural Sciences \& Natural

Resources, University of Mohaghegh Ardabili, Ardabil, 56199, Iran

*Correspondence author: E-mail: t.tseng@msstate.edu

\section{Dose-response study to evaluate dicamba tolerance in selected wild tomato germplasm}

A greenhouse dose-response study was conducted to determine the tolerance of three wild tomato accessions (TOM199, TOM198, TOM300) in comparison to a commercial cultivar (Better Boy) against the dicamba application at five rates $(0,70$, 140, 210, and $280 \mathrm{~g} \mathrm{ae} \mathrm{ha}^{-1}$ ) at 14 and 28 days after treatment (DAT). Several physiological traits were evaluated at 0,1,3, 5, and 7 DAT. Wild accessions and cultivar were killed at all rates above $70 \mathrm{~g}_{\text {ae }} \mathrm{ha}^{-1}$ at 14 and 28 DAT, which is why differences between accessions and cultivar were only evident at $70 \mathrm{~g}$ ae ha ${ }^{-1}$. The $\mathrm{GR}_{50}$ (the herbicide rate that causes $50 \%$ reduction in dry weight) of Better Boy was $4.4 \mathrm{~g}$ ae ha ${ }^{-1}$ at $28 \mathrm{DAT}$, and this cultivar was approximately 11-fold more sensitive than wild accessions. At 7 DAT, the levels of $\mathrm{H}_{2} \mathrm{O}_{2}$ for wild accessions were lower than Better Boy up to 5 at $70 \mathrm{~g}$ ae ha ${ }^{-1}$ of dicamba. Furthermore, wild accessions showed lower herbicide absorption than Better Boy at all dicamba doses at 1, 3, and 7 DAT. All the three wild accessions expressed tolerance to the dicamba application 
at the dose of $70 \mathrm{~g}$ ae ha ${ }^{-1}$. At the same time, Better Boy and wild accessions were susceptible to dicamba application at rates of 140, 210, and $280 \mathrm{~g} \mathrm{ae} \mathrm{ha}^{-1}$.

Keywords: auxin herbicide; herbicide tolerance; wild germplasm; GR 50 ; $\mathrm{HR}_{50}$; I50

\section{Introduction}

Tomato (Solanum lycopersicum L.) is one of the most important vegetables worldwide (Heuvelink and Okello 2005). Unfortunately, tomato is extremely sensitive to drift from auxin herbicides (Fagliari et al. 2005; Kruger et al. 2012; Knezevic et al. 2018; Hermes 2020). In most cases, herbicide drift from neighboring fields has been the primary reason for damage to tomato plants (Fagliari et al. 2005; Lovelace et al. 2007b).

A 2 yr study conducted to evaluate the impact of different doses of dicamba on tomato observed up to $91 \%$ injury on the crop caused by a $560 \mathrm{~g}$ ae ha ${ }^{-1}$ rate of dicamba (Hynes 2012). It was demonstrated that a dose of 3.98 to $5.35 \mathrm{~g}$ ae ha-1 (approximately $2 \%$ of the label rate) of three dicamba-based products, including Clarity®, Engenia®, and XtendiMax ${ }^{\circledR}$, caused 50\% visual injury in tomato at 21 DAT (Knezevic et al. 2018). Also, Hermes (2020) showed that the visual injury and dry weight reduction levels augmented and decreased by increasing the dicamba doses from 3.5 to $56 \mathrm{~g}$ ae ha-1. Furthermore, the marketable yield reduction was observed when dicamba drift occurred during the tomato flowering stage (Kruger et al. 2012).

High auxinic herbicide concentration induces a series of molecular and physiological processes such as differential activity of the 1-aminocyclopropane-1-carboxylic acid (ACC) synthase gene in ethylene production and/or 9-cis-epoxycarotenoid dioxygenase (NCED) gene activity in abscisic acid (ABA) biosynthesis, ethylene production, production of xanthoxin and hydrogen cyanide ( $\mathrm{HCN}$ in particular, in case of application of quinclorac), overproduction of reactive oxygen species (ROS), and ultimately resulting in plant death (Grossmann 1998; Zheng and Hall 2001; Walsh et al. 2006; Grossmann 2009; Mithila et al. 2011). Noticeably, McCauley et al. (2020) suggested that although the increase in NCED expression after application of auxinic herbicides resulted in a rapid biosynthesis of ABA, this increase in ABA levels is not dependent on an increase in ethylene levels. Romero-Puertas et al. (2004) studied the impact of 2,4-D on ROS 
metabolism of pea (Pisum sativum L.) leaves and unraveled that an increase in $\mathrm{H}_{2} \mathrm{O}_{2}$ production occurred in 2,4-D-treated plants. Additionally, increasing the IAA concentration from 0 to $25 \mathrm{nM}$ increased the concentration of $\mathrm{H}_{2} \mathrm{O}_{2}$ from 12 to $22 \mathrm{mmol} \mathrm{g}^{-1} \mathrm{f}$. wt in tomato root tips, which resulted in decreased root growth of up to $89 \%$ in wild-type tomato plants (Ivanchenko et al. 2013).

Meanwhile, the amount of auxinic herbicide absorption increases with the increase in the concentration of the applied herbicide (Greenham 1962, 1973). Increasing the concentration of 2,4-D from 3.4 to $10 \mathrm{mM}$ increased the amount of herbicide absorbed and translocated (Greenham1962). Therefore, by increasing the auxinic herbicide concentration, the herbicide absorption and activity would be augmented. Consequently, the sensitivity of herbicide-treated plants would be increased after applying auxinic herbicides at higher doses (Greenham 1973; Kruger et al. 2012; Zangoueinejad 2019). Nevertheless, determining the susceptibility level of tomato against auxinic herbicides such as dicamba would help protect the quantity and quality of tomato yield against accidental herbicide drift (Fagliari et al. 2005; Kruger et al. 2012).

According to Zangoueinejad et al. (2019), three dicamba-tolerant wild tomato accessions (TOM199, TOM198, and TOM300) were identified, showing less than 15\% visible injury against dicamba application at the rate of $2.8 \mathrm{~g}$ ae ha ${ }^{-1}$. The aim of this current study was, therefore, to distinguish the potential tolerance level of these wild accessions in response to four rates, up to the drift rate $\left(2.8 \mathrm{~g}_{\mathrm{ge} \mathrm{ha}}{ }^{-1}\right)$ of dicamba, including $70,140,210$, and $280 \mathrm{~g}$ ae ha $\mathrm{h}^{-1}$, through a doseresponse assay. Furthermore, the $\mathrm{H}_{2} \mathrm{O}_{2}$ content, the value of herbicide absorption, and herbicide distribution after applying dicamba were investigated and compared between the wild accessions and a commercial tomato cultivar (Better Boy).

\section{Materials and Methods}

\section{Greenhouse bioassay and dose-response study}

A dose-response assay to compare the response of three wild dicamba-tolerant tomato accessions (TOM199, TOM198, and TOM300) compared to a susceptible commercial tomato cultivar (Better Boy) was conducted in the greenhouse at the Department of Plant and Soil Sciences, Mississippi State University, Starkville, MS, in 2018. The assay was conducted on June 10 and repeated on July 24 . The relative humidity (70-75\%), day temperature $\left(24-26^{\circ} \mathrm{C}\right)$, night temperature $\left(18-20^{\circ} \mathrm{C}\right)$, photoperiod [11.5-13.5 (hours/day)], and light intensity (1215 $\mu$ mols s${ }^{-1}$ 
$\mathrm{m}^{-2}$ ) were kept the same during both experimental runs. Tomato seeds were sown in 72-cell trays (size of each tray: 50.8 by $25.4 \mathrm{~cm}$ ) filled with Sunshine ${ }^{\circledR} \# 2$ (SunGro ${ }^{\circledR}$ Horticulture, Quebec, Canada), and at 4-wk after emergence, seedlings were transferred into larger pots $(5 \times 4 \times 13 \mathrm{~cm})$, maintaining one plant per pot. There were 30 pots per experimental unit. Watering was done daily to field capacity, and fertigation was performed using 20:20:20 formulated fertilizer (Scotts Miracle-Gro ${ }^{\circledR}$ Company, Marysville, $\mathrm{OH}$ ) twice a week since emergence until the end of the experiment. All herbicide doses were applied on tomato plants at the 4-leaf stage using a singletip spray chamber fitted with a TP8002VS Flat spray tip (TeeJet Technologies, Wheaton, IL), calibrated to deliver $186 \mathrm{~L} \mathrm{ha}^{-1}$ at $275.79 \mathrm{kPa}$ while maintaining a constant speed of $4.8 \mathrm{KPH}$. To prevent the herbicide from reaching the soil, the surface of the pots was covered with aluminum foil at the time of the dicamba application. Visual injury [using a scale of 0 to $100 \%$; where $0 \%$ meant no injury, and 100\% meant complete plant death (Frans et al. 1986)], tomato plant height (the length in $\mathrm{cm}$ of the main stem from the base of the plant), and dry weight $\left(\mathrm{g} \mathrm{pot}^{-1}\right)$ of aboveground parts were measured 14 and 28 days after treatment (DAT). The foliage of the tomato plants was harvested at the soil surface, oven-dried at $50^{\circ} \mathrm{C}$ for $72 \mathrm{~h}$, and then weighed to determine the dry weight. Furthermore, height and dry weight reduction were calculated for all dicamba treated tomato plants and compared to control plots using equations 1 and 2, respectively, and reported as the percentage of control. To evaluate tomato yield after fruit ripening, tomato plants were transplanted into larger pots $(17 \times 12 \times 13 \mathrm{~cm})$ at $28 \mathrm{DAT}$.

$$
\begin{aligned}
& \text { Height reduction (\% of control) } \\
& =\frac{\text { Height of control plant }(\mathrm{cm})-\text { Height of treated plant }(\mathrm{cm})}{\text { Height of control plant }(\mathrm{cm})} \\
& \times 100
\end{aligned}
$$

$$
\begin{aligned}
& \text { Dry weight reduction (\% of control) } \\
& =\frac{\text { Dry weight of control plant }(\mathrm{cm})-\text { Dry weight of treated plant }(\mathrm{cm})}{\text { Dry weight of control plant }(\mathrm{cm})} \\
& \times 100
\end{aligned}
$$




\section{Absorption and distribution of dicamba}

Absorption and distribution of dicamba were compared among all tomato accessions (wild and commercial) after applying herbicide at all doses. Tomato plants were divided into two parts (leaves and roots). Dicamba extraction was conducted according to Shin et al. (2010) with slight modifications. Ethanol (50\%) was used to wash dicamba residue from the leaf surface of harvested tissues at 1, 3, and 7 DAT. A $0.5 \mathrm{~g}$ sample of the plant tissues from each part was homogenized with distilled water, agitated for $20 \mathrm{~min}$, and centrifuged at $16,100 \times g$ for $25 \mathrm{~min}$ at room temperature. The supernatant after filtering $(0.2 \mu \mathrm{m}$ pore size; VWR Scientific, Seattle, WA) was then air evaporated overnight at room temperature. After transferring the aliquot into a $25 \mathrm{~mL}$ vial, the sample was agitated for $60 \mathrm{~min}$ and then added with $20 \mathrm{~mL}$ of $5 \mathrm{M}$ hydrochloric acid-ACN $(5: 95, \mathrm{v} / \mathrm{v})$. The aliquot was evaporated to $10 \mathrm{~mL}$ and poured into a separatory funnel containing $2 \mathrm{~g}$ of sodium chloride. Thereafter, using $20 \mathrm{~mL}$ of $0.6 \mathrm{M}$ sodium hydroxide and $10 \mathrm{~mL}$ of $n$ hexane, the alkalinizing and partitioning were performed, respectively. At the subsequent step, partitioning was repeated with an additional $10 \mathrm{~mL}$ of $\mathrm{n}$-hexane after pouring off the upper hexane layer. The aqueous layer was acidified with $2 \mathrm{~mL}$ of $6 \mathrm{M}$ sulfuric acid, and the partitioning of the acidified aqueous layer using $10 \mathrm{~mL}$ dichloromethane for each partitioning was executed twice. The water content of the organic layer was cleared by passing this substrate through anhydrous sodium sulfate. The hydrated sodium sulfate was rinsed using $7 \mathrm{~mL}$ of dichloromethane and then combined with the dehydrated original extract. The final extract was evaporated to $1 \mathrm{~mL}$ using a vacuum evaporator, and the cleanup was conducted according to Shin et al. (2010). The final residues were dissolved in $2 \mathrm{~mL}$ of the mobile phase [acetic acid 0.2\% and acetonitrile (60:40, $\mathrm{v} / \mathrm{v})]$. The standard solution of dicamba was prepared by dissolution of $10.1 \mathrm{mg}$ of dicamba in 100 $\mathrm{mL}$ of acetonitrile to achieve a final concentration of $100 \mathrm{ug} \mathrm{mL} \mathrm{mL}^{-1}$. An Agilent 1100 series HPLC (Agilent, Santa Clara, CA) was used to analyze dicamba in the extracts. Processing data was performed using Agilent Chemstation A.10.02 software with a spectral module (Agilent Technologies Inc., Wilmington, DE, USA). Alltech Adsorbsphere reverse phase C18 column (150 $\mathrm{mm} \times 4.6 \mathrm{~mm}$, Dr. A. Maisch High-Performance LC GmbH, Germany) with particle size $3 \mu \mathrm{m}$ was utilized to achieve separation. The volume of injection plus wash was $5 \mu \mathrm{L}$, and the flow rate was $0.5 \mathrm{~mL} / \mathrm{min}$. A mixture that consisted of 60 and $40 \%$ of acetic acid $(0.2 \%)$ and acetonitrile, 
respectively, was used as the mobile phase. The column temperature was maintained at $25^{\circ} \mathrm{C}$. The FLD was not explicitly set, although the DAD detection was set at $280 \mathrm{~nm}$. The post and stop time was 10 and $2 \mathrm{~min}$, respectively. The concentration of dicamba was converted from $\mathrm{mg} \mathrm{L}^{-1}$ to $\mathrm{mg}$ $\mathrm{g}^{-1}$ of fresh tissue.

It should be noted that untreated plant extracts were used as a negative control to ensure that no interfering compounds eluted at the same time as dicamba and interfered with dicamba quantification. Dicamba absorption and distribution were finally reported as the percentage of applied and absorbed herbicide, respectively. To measure dicamba absorption, the amount of washed herbicide from the surface of plant leaves was taken as the initial value of applied dicamba at 0 DAT. Then, the quantified concentration of dicamba in tomato leaf tissues at 1,3, and 7 DAT was reported as the percentage of applied herbicide at 0 DAT. Dicamba distribution was measured by comparing the percentage of quantified absorbed dicamba between plant leaves and roots at 1 , 3 , and 7 DAT.

\section{Hydrogen peroxide $\left(\mathrm{H}_{2} \mathrm{O}_{2}\right)$ content assay}

The concentration of $\mathrm{H}_{2} \mathrm{O}_{2}$ was measured in leaf tissues of tomato plants at 1, 3, and 7 DAT using spectrofluorometry after application of dicamba at $0,70,140,210$, and $280 \mathrm{~g}$ ae ha ${ }^{-1}$, as described previously by Guilbault et al. (1967). The concentration of $\mathrm{H}_{2} \mathrm{O}_{2}$ was reported as $\mu$ mole $(\mathrm{g} \mathrm{FW})^{-1}$.

All operations to quantify the concentration of $\mathrm{H}_{2} \mathrm{O}_{2}$ in tomato plant leaf tissues were carried out at $4^{\circ} \mathrm{C}$. After homogenizing $0.4 \mathrm{~g}$ of leaf tissues in $1.2 \mathrm{~mL} 25 \mathrm{mM} \mathrm{HCl}$, two nylon layers were used to filter crude extracts. Then, pigments were removed from the resulting crude extract using $15 \mathrm{mg}$ of charcoal (Sigma-Aldrich, St Louis, MO, USA) and centrifuged at $5000 \mathrm{~g}$ for $5 \mathrm{~min}$. Clarification of the supernatant was done by passing through a 0.22 -mm filter unit (Whatman 7402-001 Filter Circles, Maidstone, United Kingdom). Also, before measuring the $\mathrm{H}_{2} \mathrm{O}_{2}$ concentration, the $\mathrm{pH}$ of leaf extracts was adjusted to 7.0 using $\mathrm{NaOH}$. The reaction mixtures (3 mL) contained $50 \mathrm{mM}$ Hepes buffer ( $\mathrm{pH} 7.6$ ), $5 \mathrm{mM}$ homovanillic acid, and $100 \mathrm{~mL}$ of extract. The reaction was started by adding $40 \mathrm{mM}$ horseradish peroxidase, and the fluorescence produced was measured in a spectrofluorophotometer (NanoDrop-ND-10000, Thermo Scientific, Waltham, MA) at excitation and emission wavelengths of 315 and $425 \mathrm{~nm}$, respectively. 


\section{Statistical analysis}

The greenhouse bioassay was arranged in a factorial experiment in a completely randomized design with three replications and two runs. Notably, all experiments and measurements were carried out in three biological replicates.

The factors included dicamba (Clarity, BASF Corp., Florham Park, NJ) rates with five levels [0 (0X; as control), $70(0.25 \mathrm{X}), 140(0.5 \mathrm{X}), 210(0.75 \mathrm{X})$, and $280(1 \mathrm{X}) \mathrm{g} \mathrm{ae} \mathrm{ha}^{-1}$ ] and tomato lines in four levels (three wild accessions including TOM199, TOM198, TOM300; and one commonly grown cultivar, Better Boy). All experiments were repeated twice with three plants per time point after each experimental run of the greenhouse bioassay.

Data from all experiments were tested to evaluate normality using plotting QQ [quantilequantile] plots for residuals in GraphPad Prism 8 (GraphPad Software, San Diego, CA, USA). Since data met normality conditions, data transformation was not conducted. Data were combined across experimental runs (in each experiment) because no experimental run or run by factor (treatment) interactions were significant for either experiment. The homogeneity was checked based on the Levene's test. All data were subjected to ANOVA using PROC MIXED SAS 9.4 (SAS Institute, Cary, NC, USA), and means were separated using LSD's-test at $P \leq 0.05$.

Herbicide dose-response data for visual injury, height, and dry weight were analyzed using a three-parameter log-logistic model (equation 3) to determine a dose of dicamba that causes $50 \%$ injury ( $\left.\mathrm{I}_{50}\right)$, height reduction $\left(\mathrm{HR}_{50}\right)$, and dry weight reduction $\left(\mathrm{GR}_{50}\right)$ at 14 and 28 DAT. This analysis was performed using SAS 9.4 (SAS Institute, Cary, NC, USA).

$$
\mathrm{Y}=\frac{d}{1+\exp \{b[\log (x)-\log (e)]\}}
$$

Where $\mathrm{Y}$ is the plant response, the parameter $\mathrm{d}$ is the upper limit, $b$ is the slope of the curve, $x$ is the herbicide dose, and $e$ is the herbicide dose that causes $50 \%$ visual injury, height reduction, or dry weight reduction. The lower limit of the herbicide dose is set to 0 in this experiment. The significant differences between estimated $\mathrm{I}_{50}, \mathrm{HR}_{50}$, and $\mathrm{GR}_{50}$ values were determined using an independent $t$-test (Welch's t-test) to recognize the significant differences in parameter estimates 
between tomato lines (including wild accessions and commercial cultivar) to estimate the values of tolerance indices based on the values of $\mathrm{I}_{50}$ [Tolerant $\mathrm{T}_{50} / \mathrm{Susceptible}_{\mathrm{I}_{50}}\left(\mathrm{~T}_{\mathrm{I5} /} / \mathrm{S}_{\mathrm{I50}}\right.$ ratio)], $\mathrm{HR}_{50}$ $\left[\right.$ Tolerant $_{\mathrm{HR} 50} /$ Susceptible $_{\mathrm{HR} 50} \quad\left(\mathrm{~T}_{\mathrm{HR} 50} / \mathrm{S}_{\mathrm{HR} 50}\right.$ ratio)], and $\mathrm{GR}_{50} \quad$ [Tolerant ${ }_{\mathrm{GR} 50} /$ Susceptible $_{\mathrm{GR} 50}$ $\left(\mathrm{T}_{\mathrm{GR} 50} / \mathrm{S}_{\mathrm{GR} 50}\right.$ ratio)]. Moreover, fitted dose-response curves based on different independent variables (level of visual injury, height reduction, and dry weight reduction) at each time point were compared among tomato lines by contrasting the best-fit values using one-way ANOVA. All graphs were drawn using GraphPad Prism 8 (GraphPad Software, San Diego, CA, USA).

\section{Results and discussion}

\section{Visual injury}

Overall, the level of visual injury increased in all wild tomato accessions and cultivar when the rate of dicamba was increased from 70 to $280 \mathrm{~g}$ ae ha ${ }^{-1}$. However, all accessions and cultivar generally exhibited similar injury at all rates (Figure 1; Table 1).

Table 1. The level of visual injury, plant height, and dry weight of wild accessions and cultivar after application of dicamba at five rates.

\begin{tabular}{|c|c|c|c|c|c|c|c|}
\hline \multirow{2}{*}{$\begin{array}{l}\text { Dicamba } \\
\text { dose } \\
\mathrm{g} \text { ae } \mathrm{ha}^{-1}\end{array}$} & \multirow{2}{*}{$\begin{array}{l}\text { Tomato } \\
\text { lines }\end{array}$} & \multicolumn{3}{|c|}{$14 \mathrm{DAT}^{\mathrm{a}}$} & \multicolumn{3}{|c|}{$28 \mathrm{DAT}$} \\
\hline & & $\begin{array}{l}\text { Injury } \\
\%\end{array}$ & $\begin{array}{l}\text { Height } \\
\mathrm{cm}\end{array}$ & $\begin{array}{l}\text { Dry } \\
\text { weight } \\
\text { g plot }^{-1}\end{array}$ & $\begin{array}{l}\text { Injury } \\
\%\end{array}$ & $\begin{array}{l}\text { Height } \\
\mathrm{cm}\end{array}$ & $\begin{array}{l}\text { Dry } \\
\text { weight } \\
\text { g plot }^{-1}\end{array}$ \\
\hline \multirow[t]{4}{*}{0} & TOM199 & $\begin{array}{c}0.0 \\
( \pm 0.0)^{\mathrm{b}} \mathrm{e}^{\mathrm{c}}\end{array}$ & $\begin{array}{c}33.0 \\
( \pm 0.5) \mathrm{a}\end{array}$ & $\begin{array}{c}15.4 \\
( \pm 0.2) \mathrm{a}\end{array}$ & $\begin{array}{c}0.0 \\
( \pm 0.0) \mathrm{c}\end{array}$ & $\begin{array}{c}45.1 \\
( \pm 0.8) \mathrm{c}\end{array}$ & $\begin{array}{c}20.8 \\
( \pm 0.1) \mathrm{a}\end{array}$ \\
\hline & TOM198 & $\begin{array}{c}0.0 \\
( \pm 0.0) \mathrm{e}\end{array}$ & $\begin{array}{c}32.0 \\
( \pm 0.3) \mathrm{a}\end{array}$ & $\begin{array}{c}15.9 \\
( \pm 0.3) \mathrm{a}\end{array}$ & $\begin{array}{c}0.0 \\
( \pm 0.0) \mathrm{c}\end{array}$ & $\begin{array}{c}44.9 \\
( \pm 0.8) \mathrm{c}\end{array}$ & $\begin{array}{c}20.9 \\
( \pm 0.2) \mathrm{a}\end{array}$ \\
\hline & TOM300 & $\begin{array}{c}0.0 \\
( \pm 0.0) \mathrm{e}\end{array}$ & $\begin{array}{c}34.0 \\
( \pm 1.2) \mathrm{a}\end{array}$ & $\begin{array}{c}16.4 \\
( \pm 0.1) \mathrm{a}\end{array}$ & $\begin{array}{c}0.0 \\
( \pm 0.0) \mathrm{c}\end{array}$ & $\begin{array}{c}47.9 \\
( \pm 0.3) b\end{array}$ & $\begin{array}{c}21.3 \\
( \pm 0.2) \mathrm{a}\end{array}$ \\
\hline & Better Boy & $\begin{array}{c}0.0 \\
( \pm 0.0) \mathrm{e}\end{array}$ & $\begin{array}{c}35.0 \\
( \pm 0.9) a\end{array}$ & $\begin{array}{c}15.8 \\
( \pm 0.5) a\end{array}$ & $\begin{array}{c}0.0 \\
( \pm 0.0) c\end{array}$ & $\begin{array}{c}51.5 \\
( \pm 0.7) a\end{array}$ & $\begin{array}{c}21.4 \\
( \pm 0.3) a\end{array}$ \\
\hline \multirow[t]{3}{*}{70} & TOM199 & $\begin{array}{c}38.0 \\
( \pm 2.0) \mathrm{d}\end{array}$ & $\begin{array}{c}21.0 \\
( \pm 0.6) \mathrm{b}\end{array}$ & $\begin{array}{c}9.6 \\
( \pm 0.2) b\end{array}$ & $\begin{array}{c}33.0 \\
( \pm 3.8) \mathrm{c}\end{array}$ & $\begin{array}{c}19.5 \\
( \pm 0.9) \mathrm{e}\end{array}$ & $\begin{array}{c}10.1 \\
( \pm 0.1) b\end{array}$ \\
\hline & TOM198 & $\begin{array}{c}42.0 \\
( \pm 1.5) \mathrm{d}\end{array}$ & $\begin{array}{c}19.0 \\
( \pm 0.8) \mathrm{b}\end{array}$ & $\begin{array}{c}9.3 \\
( \pm 0.1) b\end{array}$ & $\begin{array}{c}37.0 \\
( \pm 5.2) \mathrm{c}\end{array}$ & $\begin{array}{c}18.4 \\
( \pm 0.4) \mathrm{e}\end{array}$ & $\begin{array}{c}9.9 \\
( \pm 0.2) b\end{array}$ \\
\hline & TOM300 & $\begin{array}{c}42.0 \\
( \pm 3.2) \mathrm{d}\end{array}$ & $\begin{array}{c}21.0 \\
( \pm 0.5) \mathrm{b}\end{array}$ & $\begin{array}{c}9.4 \\
( \pm 0.2) \mathrm{b}\end{array}$ & $\begin{array}{c}36.0 \\
( \pm 3.5) \mathrm{c}\end{array}$ & $\begin{array}{c}21.3 \\
( \pm 0.5) \mathrm{d}\end{array}$ & $\begin{array}{c}10.3 \\
( \pm 0.2) b\end{array}$ \\
\hline
\end{tabular}




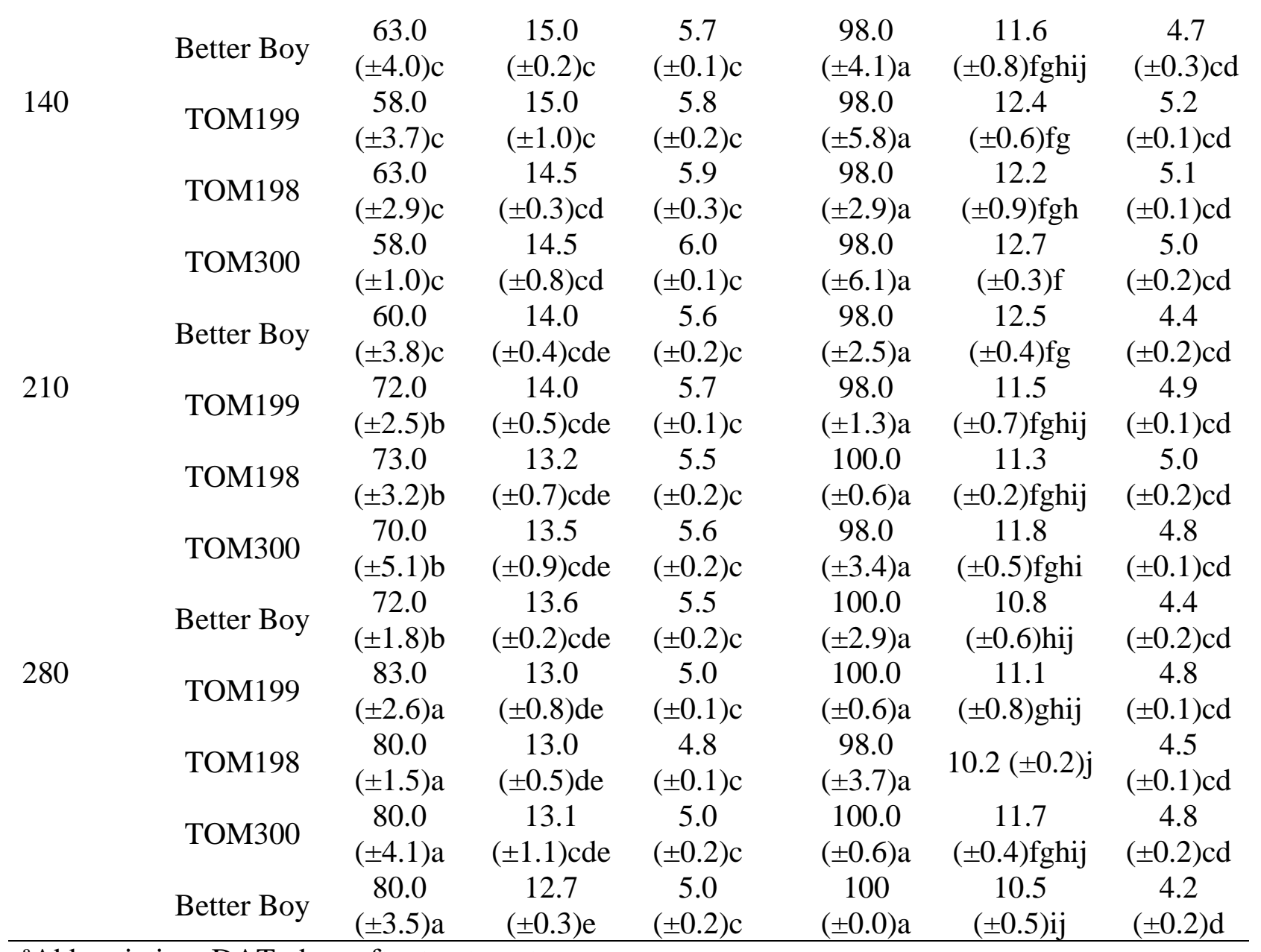

${ }^{a}$ Abbreviation: DAT, days after treatment.

${ }^{\mathrm{b} S t a n d a r d}$ Error.

${ }^{\mathrm{c}}$ Means within columns followed by the different letter are significantly different at $\mathrm{P} \leq 0.05$ using LSD's test. 

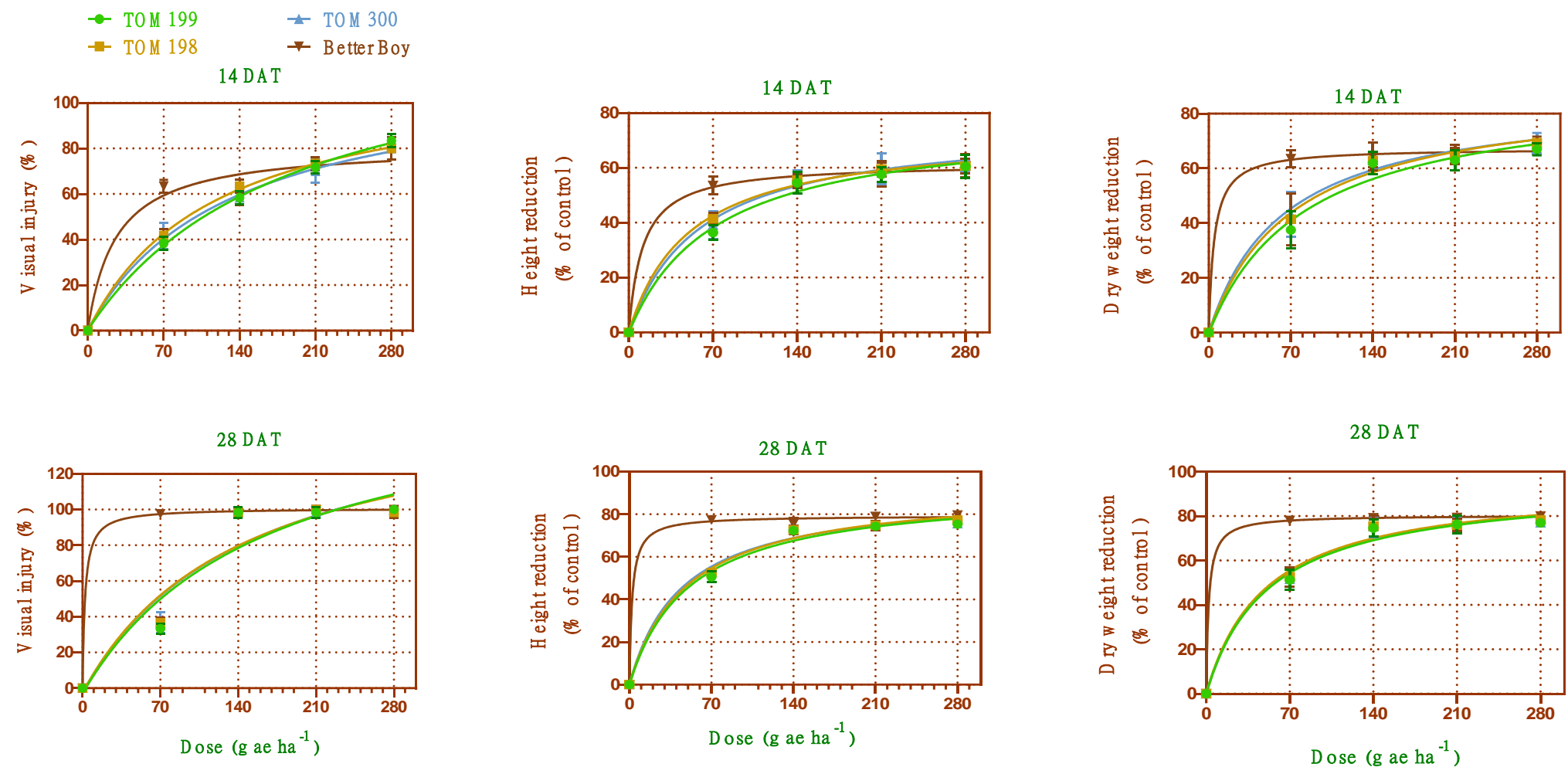

Figure 1. Response of wild tomato accessions and cultivar based on the level of visible injury and reduction in plant height and dry weight after dicamba application at five rates. The SE of the mean is represented by vertical bars. *Abbreviation: DAT, days after treatment. 
The wild accessions showed slight injury after applying dicamba at the lowest rate of $70 \mathrm{~g}$ $\mathrm{ae} \mathrm{ha}^{-1}$ at both timings; however, the injury of the three wild accessions was about $30 \%$ lower than the Better Boy cultivar. Better Boy showed an injury of up to $60 \%$ after applying dicamba at the rate of $70 \mathrm{~g}_{\text {ae }} \mathrm{ha}^{-1}$. In line with our results, several studies demonstrated that the application of dicamba is harmful to tomato even at low doses (Gilreath et al. 2001; Lovelace et al. 2007b; Kruger et al. 2012). The phytotoxicity of glyphosate and dicamba drift was evaluated on dry edible pea (Pisum sativum L.), dry edible bean (Phaseolus vulgaris L.), and potato (Solanum tuberosum L.) (Hatterman-Valenti et al. 2017). Results indicated that the effect of dicamba (even at low rates) was more detrimental to crops than glyphosate. Mohseni-Moghadam and Doohan (2015) reported visual injury was observed on the leaves and shoots of bell pepper (Capsicum annuum L.) and broccoli (Brassica oleracea L. var, botrytis L.) after the application of dicamba at five different rates $\left(11.2\right.$, 5.6, 3.696, 2.8, and $1.4 \mathrm{~g}$ ae ha $\left.{ }^{-1}\right)$. Colquhoun et al. (2014) demonstrated the visual injury increased from 19 to $45 \%$ on snap bean (Phaseolus vulgaris L.) leaves when dicamba concentration was increased from 1.2 to $7 \mathrm{~g}$ ae ha ${ }^{-1}$.

Among the wild accessions, TOM199 showed the highest $\mathrm{I}_{50}$ value of 188.4 and $40.48 \mathrm{~g}$ ae ha $^{-1}$ at 14 and 28 DAT, respectively (Table 2$)$. These values were higher than TOM198 $(\mathrm{P}<0.05)$, TOM300 ( $<<0.01)$, and Better Boy $(\mathrm{P}<0.001)$ at 14 DAT. At 28 DAT, the $\mathrm{I}_{50}$ values were similar among the wild accessions but were higher than Better Boy $(\mathrm{P}<0.001)$ (Figure 1). The values of I50 for TOM199, TOM198, TOM300, and Better Boy were 40.4, 38, 38.2, and $1.5 \mathrm{~g}^{\text {ae }} \mathrm{ha}^{-1}$, respectively. Moreover, the dose-response curves for all three wild accessions were different $(\mathrm{P}<0.001)$ compared to Better Boy at 28 DAT (Figure 1). The tolerance indices for TOM199, TOM198, and TOM300 at 28 DAT were 4, 6, and 5-fold higher than 14 DAT, respectively (Table 2).

\section{Plant Height}

The wild accessions and cultivar were shorter than their control plants after applying dicamba at all doses (Figure 1; Table 1). The plant height was reduced with an increase in the dicamba rate. More importantly, TOM199, TOM198, TOM300, and Better Boy did not display any difference in plant height at dicamba rates of 140, 210, and $280 \mathrm{~g}^{\mathrm{ae} \mathrm{ha}}{ }^{-1}$ (Figure 1; Table 1).

Wild tomato accessions were taller than Better Boy when dicamba was applied at the rate of $70 \mathrm{~g}$ ae $\mathrm{ha}^{-1}$; the height of TOM199, TOM198, TOM300, and Better Boy was 21, 19, 21, and 
$15 \mathrm{~cm}$, respectively, at 14 DAT (Figure 1; Table 1). At 28 DAT, The plant height of TOM199, TOM198, and TOM300 was 68, 59, and 84\% higher than Better Boy, respectively, at the rate of $70 \mathrm{~g}_{\text {ae ha }}{ }^{-1}$ (Figure 1; Table 1). Although all the wild accessions showed signs of recovery at 28 DAT, Better Boy did not, resulting in a $29 \%$ height reduction from 14 to 28 DAT (Figure 1; Table 1).

The estimated HR 50 for TOM3199, TOM198, and TOM300 were 72, 50, and $59 \mathrm{~g}^{\mathrm{ae} \mathrm{ha}}{ }^{-1}$, respectively, and higher $(\mathrm{P}<0.001)$ than Better Boy $\left(11.5 \mathrm{~g} \mathrm{ae} \mathrm{ha}^{-1}\right)$, at 14 DAT (Table 2). At 28 DAT, the values of $\mathrm{HR}_{50}$ for TOM3199, TOM198, and TOM300 were 51, 49, and $45 \mathrm{~g}_{\text {ae ha }}{ }^{-1}$, respectively, which was up to 22 folds higher $(\mathrm{P}<0.001)$ than Better Boy (Table 2). Although the estimated values of $\mathrm{HR}_{50}$ for TOM199 were higher $(\mathrm{P}<0.05)$ than TOM199 and TOM300 at 14 DAT, they were not different at 28 DAT (Table 2). The differences in the dose-response curves between wild accessions and Better Boy were significant only at 28 DAT (Figure 1). Based on the tolerant indices, TOM199, TOM198, and TOM300 showed a T/S ratio of 6.3, 4.2, and 5.1, respectively, at $14 \mathrm{DAT}$; this ratio was approximately 4-fold for all wild accessions, at $28 \mathrm{DAT}$ (Table 2).

\section{Dry weight}

Similar to the results of the plant visual injury and height reduction, the dry weight of TOM199, TOM198, TOM300, and Better Boy was decreased in response to increasing dicamba application doses from 70- $280 \mathrm{~g}$ ae ha- ${ }^{-1}$, at 14 and 28 DAT. No difference was observed between the dry weight of tomato wild accessions and cultivar after the application of dicamba at the doses of 140, 210, and $280 \mathrm{~g}$ ae ha $^{-1}$ over time (Figure 1; Table 1).

The recorded dry weight of wild accessions was approximately 1.7 and 2.1-fold higher than Better Boy at 14 and 28 DAT, respectively, after the application of dicamba at the rate of $70 \mathrm{~g}$ ae ha $^{-1}$ (Figure 1; Table 1). The dry weight of TOM199, TOM198, TOM300, and Better Boy was 9.6, 9.3, 9.4, and 5.7 g plot $^{-1}$, respectively, at 14 DAT (Table 1). In agreement with the results of two other studied traits, including visual injury and plant height, the level of dry weight was increased for all three wild accessions from 14 to 28 DAT after the application of dicamba at the dose of 70 $\mathrm{g}$ ae ha-1 (Figure 1; Table 1). At 28 DAT, 10.1, 9.9, and $10.3 \mathrm{~g} \mathrm{plot}^{-1}$ dry weight was recorded for TOM199, TOM198, and TOM300, respectively, while this was reduced for Better Boy by up to $4.7 \mathrm{~g} \mathrm{plot}^{-1}$ at $28 \mathrm{DAT}$ (Table 1). 
The estimated values of $\mathrm{GR}_{50}$ for Better Boy were lower $(\mathrm{P}<0.001)$ than TOM199, TOM198, and TOM300 by 17, 15, and 13-fold, at 14 DAT, respectively (Table 2). The values of $\mathrm{GR}_{50}$ for TOM199, TOM198, and TOM300 were higher $(\mathrm{P}<0.001)$ by approximately 24-fold compared to Better Boy at 28 DAT (Table 2). The GR $_{50}$ for TOM199 (81.8 $\mathrm{g} \mathrm{ae} \mathrm{ha}^{-1}$ ) was higher $(\mathrm{P}<0.05)$ than TOM198 (71.4 $\mathrm{g}$ ae ha $\left.{ }^{-1}\right)$ and TOM300 (63.5 $\left.\mathrm{g} \mathrm{ae} \mathrm{ha}^{-1}\right)$ at 14 DAT (Table 2), but were not different at 28 DAT (Table 2). The tolerance indices for wild accessions were higher at 28 DAT than 14 DAT (Table 2). 
Table 2. The values of $\mathrm{I}_{50}, \mathrm{HR}_{50}$, and $\mathrm{GR}_{50}$ for wilds accessions and cultivar at 14 and $28 \mathrm{DAT}$.

\begin{tabular}{|c|c|c|c|c|c|c|c|c|c|c|c|c|}
\hline \multirow{2}{*}{$\begin{array}{l}\text { Tomato } \\
\text { lines }\end{array}$} & \multicolumn{6}{|c|}{$14 \mathrm{DAT}^{\mathrm{a}}$} & \multicolumn{6}{|c|}{$28 \mathrm{DAT}$} \\
\hline & $\begin{array}{l}\mathrm{I}_{50}{ }^{\mathrm{b}} \\
-\mathrm{g} \text { ae } \mathrm{ha}^{-} \\
1_{-}\end{array}$ & $\begin{array}{l}\mathrm{I}_{50} \\
\mathrm{~T} / \mathrm{S}^{\mathrm{e}}\end{array}$ & $\begin{array}{l}\mathrm{HR}_{50}{ }^{\mathrm{c}} \\
-\mathrm{g} \text { ae ha- } \\
1_{-}\end{array}$ & $\begin{array}{l}\mathrm{HR}_{50} \\
\mathrm{~T} / \mathrm{S}^{\mathrm{f}}\end{array}$ & $\begin{array}{l}\mathrm{GR}_{50}{ }^{\mathrm{d}} \\
-\mathrm{g} \text { ae } \mathrm{ha}^{-} \\
1_{-}\end{array}$ & $\begin{array}{l}\mathrm{GR}_{50} \\
\mathrm{~T} / \mathrm{S}^{\mathrm{g}}\end{array}$ & $\begin{array}{l}\mathrm{I}_{50} \\
-\mathrm{g} \text { ae ha-1 }\end{array}$ & $\begin{array}{l}\mathrm{I}_{50} \\
\mathrm{~T} / \mathrm{S}\end{array}$ & $\begin{array}{l}\mathrm{HR}_{50} \\
-\mathrm{g} \text { ae ha-1. }\end{array}$ & $\begin{array}{l}\mathrm{HR}_{50} \\
\mathrm{~T} / \mathrm{S}^{\mathrm{e}}\end{array}$ & $\begin{array}{l}\mathrm{GR}_{50} \\
-\mathrm{g} \text { ae ha } \\
1_{-}\end{array}$ & $\begin{array}{l}\mathrm{GR}_{50} \\
\mathrm{~T} / \mathrm{S}\end{array}$ \\
\hline TOM199 & $\begin{array}{l}188.4 \\
(143.1- \\
255.2)^{\mathrm{h}} \mathrm{e} \\
118.0\end{array}$ & 7.2 & $\begin{array}{l}72.1 \\
(46.5- \\
110.1) \\
50.3\end{array}$ & 6.3 & $\begin{array}{l}81.8 \\
(46.2- \\
143.5) \\
71.4\end{array}$ & 17.4 & $\begin{array}{l}40.4 \\
(18.6- \\
71.3) \\
38.1\end{array}$ & 25.3 & $\begin{array}{l}50.9 \\
(35.5- \\
70.8) \\
48.5\end{array}$ & 22.1 & $\begin{array}{l}51.9 \\
(31.9- \\
80.1) \\
49.5\end{array}$ & 24.7 \\
\hline TOM198 & $\begin{array}{l}(87.8- \\
160.6) \\
131.5\end{array}$ & 4.5 & $\begin{array}{l}(36.1- \\
68.2) \\
59.1\end{array}$ & 4.2 & $\begin{array}{l}(40.2- \\
123.5) \\
63.5\end{array}$ & 15.1 & $\begin{array}{l}(17.8- \\
66.2) \\
38.2\end{array}$ & 23.8 & $\begin{array}{l}(35.9- \\
64.0) \\
44.4\end{array}$ & 21.0 & $\begin{array}{l}(31.1 \text { to } \\
75.1) \\
51.2\end{array}$ & 23.5 \\
\hline TOM300 & $\begin{array}{l}(84.9- \\
212.4)\end{array}$ & 5.0 & $\begin{array}{l}(34.8- \\
95.7)\end{array}$ & 5.1 & $\begin{array}{l}(37.6- \\
103.5)\end{array}$ & 13.5 & $\begin{array}{l}(17.8- \\
66.5)\end{array}$ & 23.8 & $\begin{array}{l}(31.6- \\
60.4)\end{array}$ & 19.3 & $\begin{array}{l}(32.1- \\
77.8)\end{array}$ & 24.3 \\
\hline $\begin{array}{l}\text { Better } \\
\text { Boy }\end{array}$ & $\begin{array}{l}26.0 \\
(5.5- \\
59.1)\end{array}$ & - & $\begin{array}{l}11.5 \\
(1.5- \\
24.0) \\
\end{array}$ & - & $\begin{array}{l}4.7 \\
(3.9- \\
13.5) \\
\end{array}$ & - & $\begin{array}{l}1.5 \\
(0.4-2.7)\end{array}$ & - & $\begin{array}{l}2.3 \\
(0.0002- \\
6.3)\end{array}$ & & $\begin{array}{l}2.1 \\
(0.6-3.7)\end{array}$ & - \\
\hline
\end{tabular}

${ }^{\mathrm{a} A b b r e v i a t i o n: ~ D A T, ~ d a y s ~ a f t e r ~ t r e a t m e n t . ~}$

${ }^{\mathrm{b}}$ Dose of herbicide required to damage plants up to $50 \%$.

${ }^{\mathrm{c}}$ Dose of herbicide required to reduce the plant height up to $50 \%$.

${ }^{\mathrm{d}}$ Dose of herbicide required to reduce the plant dry weight up to $50 \%$.

${ }^{\mathrm{e}} \mathrm{T} / \mathrm{S}$ ratio (tolerance index) is calculated as ratio of $\mathrm{I}_{50}$ of potential tolerant accessions to $\mathrm{I}_{50}$ of susceptible cultivar (Better Boy).

${ }^{\mathrm{f}} \mathrm{T} / \mathrm{S}$ ratio (tolerance index) is calculated as ratio of $\mathrm{HR}_{50}$ of potential tolerant accessions to $\mathrm{HR}_{50}$ of susceptible cultivar (Better Boy).

${ }^{\mathrm{g}} \mathrm{T} / \mathrm{S}$ ratio (tolerance index) is calculated as ratio of $\mathrm{GR}_{50}$ of potential tolerant accessions to $\mathrm{GR}_{50}$ of susceptible cultivar (Better

Boy).

${ }^{\mathrm{h}}$ Confidence intervals. 


\section{Tomato yield}

All plants of TOM199, TOM198, TOM300, and Better Boy did not produce any fruits at dicamba rates of 140, 210, $280 \mathrm{~g}_{\text {ae ha }}{ }^{-1}$; and at $70 \mathrm{~g}$ ae ha- ${ }^{-1}$ for Better Boy. Severe injury from the herbicide was the primary reason for plant death at these rates.

Therefore, only the yield data of wild accessions treated with $70 \mathrm{~g}$ ae ha $\mathrm{ha}^{-1}$ of dicamba are presented (Figure 2). The fruit yield of dicamba-treated TOM199, TOM198, and TOM300 at the dose of $70 \mathrm{~g}_{\text {ae }} \mathrm{ha}^{-1}$ was 51,48 , and $50 \mathrm{~g}$ plant $^{-1}$, respectively, and was not different from each other. However, TOM199, TOM198, and TOM300 showed a reduced yield than their control (Figure 2). Among non-treated wild accessions, TOM300 produced the highest yield of $132 \mathrm{~g}$ plant $^{-1}$ (Figure 2). As demonstrated by other studies, dicamba can cause a reduction in tomato fruit weight even at low doses, and this reduction increases with an increase in the herbicide dose (Kruger et al. 2012). In a greenhouse experiment, tomato fruit weight was reduced by 8 to $66 \%$ on increasing dicamba concentration from 0.001 to $0.01 \mathrm{mg} \mathrm{L}^{-1}$ (Schmoll et al. 2000).

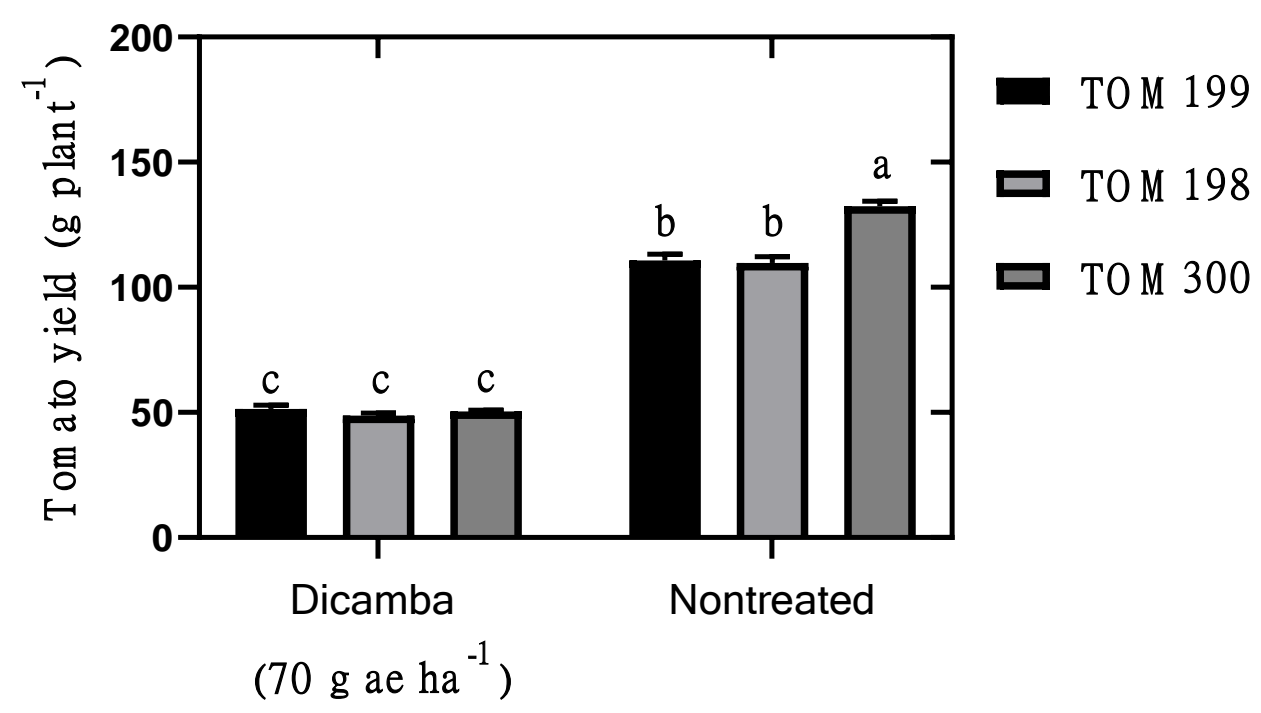

Figure 2. Comparison of the effect of dicamba treatments on the tomato yield tomato among wild accessions. Means within columns followed by different letters are significantly different at $\mathrm{P} \leq 0.05$ using LSD's test. 


\section{$\mathrm{H}_{2} \mathrm{O}_{2}$ content assay}

In the dose-response experiment, the levels of $\mathrm{H}_{2} \mathrm{O}_{2}$ were quantified from the leaf tissues of dicamba treated accessions and cultivar (Figure 3). As expected, the levels of this compound, indicating auxin herbicide activity, were increased in all wild accessions and Better Boy after application of dicamba at all doses at 1,3, and 7 DAT (Figure 3). Additionally, by increasing the dicamba rate, the quantity of $\mathrm{H}_{2} \mathrm{O}_{2}$ was increased in leaf tissues of the wild accessions and commercial cultivar over time (Figure 3). Accessions and cultivar had similar $\mathrm{H}_{2} \mathrm{O}_{2}$ levels after applying dicamba at the rate of 140, 210, and $280 \mathrm{~g}$ ae ha $^{-1}$ at $0,1,3$, and 7 DAT (Figure 3). There is evidence that after the application of $2,4-\mathrm{D}$ at $22.6 \mathrm{mM}$ concentration, the $\mathrm{H}_{2} \mathrm{O}_{2}$ content was drastically increased in pea leaf tissues compared to the control treatment (Romero-Puertas et al. 2004). Grossmann et al. (2001) asserted that the level of $\mathrm{H}_{2} \mathrm{O}_{2}$ in shoot tissues of cleavers (Galium aparine L.) following the application of $10 \mu \mathrm{M}$ of quinmerac was raised by 1.8 -fold compared to the control (no quinmerac) at $72 \mathrm{~h}$ after herbicide treatment.
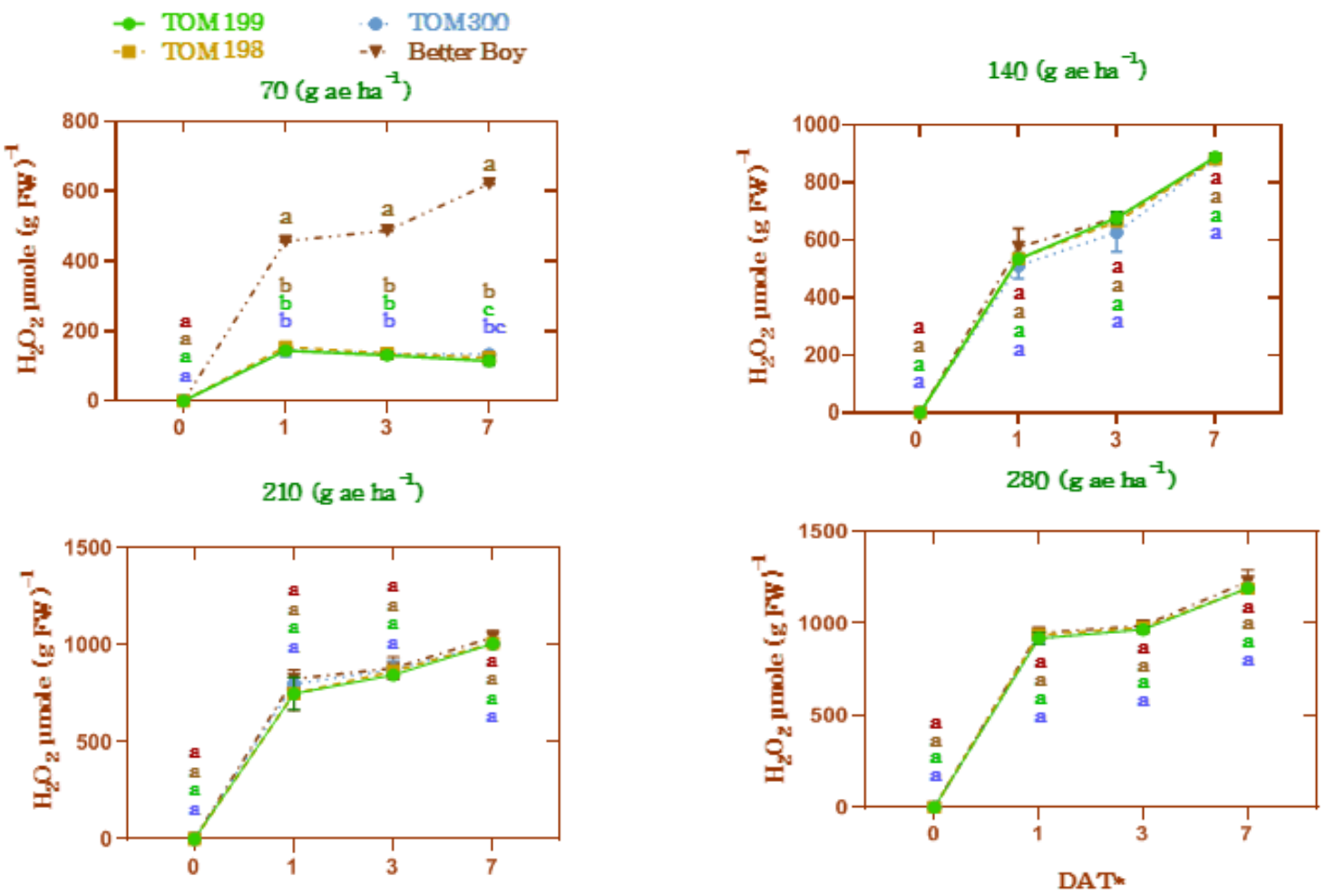
Figure 3. Comparison of concentration of $\mathrm{H}_{2} \mathrm{O}_{2}$ for TOM199, TOM198, TOM300, and Better Boy after application of dicamba at the rate of 70, 140, 210, and $280 \mathrm{~g}$ ae ha $\mathrm{ha}^{-1}$ among all time points $(0$, 1, 3, and 7 DAT). Means within each time point, followed by the different letters, are significantly different at $\mathrm{P} \leq 0.05$ using LSD's test. The SE of the mean is represented by vertical bars. *Abbreviation: DAT, days after treatment.

However, after dicamba treatment at the dose of $70 \mathrm{~g}$ ae ha ${ }^{-1}$, the level of quantified $\mathrm{H}_{2} \mathrm{O}_{2}$ from all three wild accessions leaf tissues was lower than Better Boy at 1, 3, and 7 DAT (Figure 3). The level of recorded $\mathrm{H}_{2} \mathrm{O}_{2}$ for Better Boy was $457.3 \mu$ mole $(\mathrm{g} \mathrm{FW})^{-1}$, while it was 144.1, 155, and $146.7 \mu$ mole $\left(\mathrm{g} \mathrm{FW}^{-1}\right.$ for TOM199, TOM198, and TOM300, respectively, at 1 DAT (Figure 3). Although the $\mathrm{H}_{2} \mathrm{O}_{2}$ value increased up to $487.5 \mu$ mole $(\mathrm{g} \mathrm{FW})^{-1}$ in Better Boy leaf tissues, wild accessions approximately displayed $135 \mu$ mole $\left(\mathrm{g} \mathrm{FW}^{-1}\right.$ of $\mathrm{H}_{2} \mathrm{O}_{2}$ at 3 DAT (Figure 3). Also, the $\mathrm{H}_{2} \mathrm{O}_{2}$ content in the leaves of wild accessions was lesser than Better Boy by approximately 5-fold at 7 DAT (Figure 3).

\section{Absorption and distribution}

All wild accessions and cultivar displayed a similar trend in the absorption of dicamba after application at all rates (Figure 4). However, Better Boy absorbed dicamba more than wild accessions after the application of herbicide at the dose of 70, 140, 210, and $280 \mathrm{~g}$ ae ha $^{-1}$ (Figure 4). The absorption of dicamba by Better Boy was higher than wild accessions by 29, 25, 25, and $26 \%$ at the rate of $70,140,210$, and $280 \mathrm{~g}$ ae ha ${ }^{-1}$, respectively, at 7 DAT (Figure 4). Generally, the value of herbicide absorption was increased by raising the dose of applied dicamba (Figure 4).

The wild accessions and cultivar retained most of the absorbed dicamba in their leaf tissues and did not distribute into root tissues after dicamba application at 1, 3, and 7 DAT (Table 3). Similarly, in our previous study (Zangoueinejad et al. 2020a), we indicated that TOM198, TOM199, and TOM300 absorbed a lower amount of dicamba than two commercial tomato cultivars (Better Boy and Money Maker) after herbicide application at the drift rate (2.8 $\mathrm{g} \mathrm{ae} \mathrm{ha}^{-}$ $\left.{ }^{1}\right)$. However, no difference in the herbicide distribution pattern was observed between them. Furthermore, Kohler et al. (2004) observed that the translocation pattern was similar between 2,4 D-susceptible (S) ground ivy (Glechoma hederacea L.) and 2,4-D-resistant (R) ground ivy. 

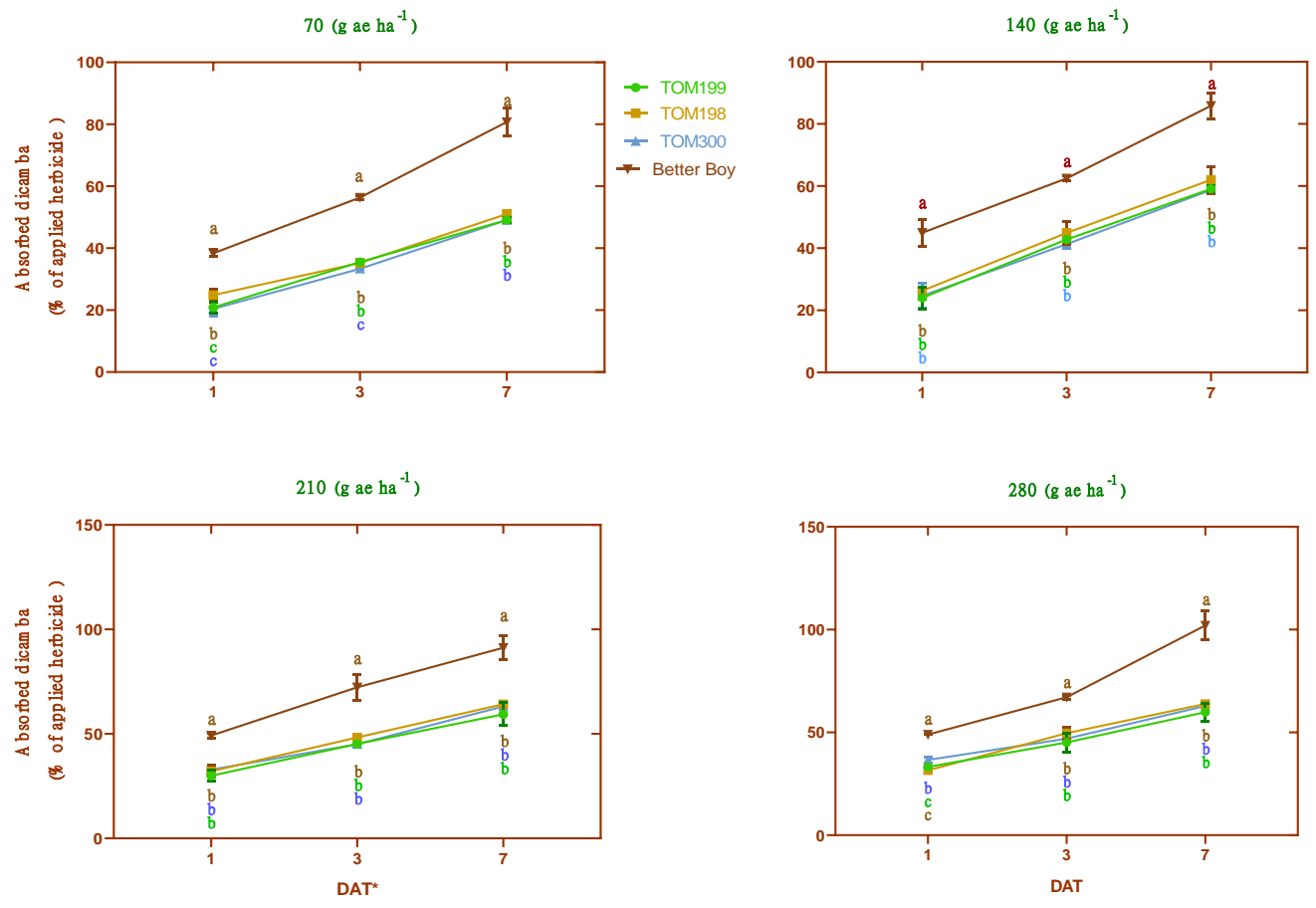

Figure 4. Comparison of the value of dicamba absorption among TOM199, TOM198, TOM300, and Better Boy after application of dicamba at 1,3, and 7 DAT. Means within each time point, followed by the different letters, are significantly different at $\mathrm{P} \leq 0.05$ using LSD's test. The SE of the mean is represented by vertical bars. *Abbreviation: DAT, days after treatment.

Table 3. Comparison of the value of dicamba distribution among TOM199, TOM198, TOM300, and Better Boy after application of dicamba at the rate of $0,70,140,210$, and $280 \mathrm{~g}$ ae ha $\mathrm{ha}^{-1}$ at 1,3 , and 7 DAT.

\begin{tabular}{|c|c|c|c|c|c|c|c|}
\hline \multirow{2}{*}{$\begin{array}{c}\text { Dicamba } \\
\text { dose } \\
\text { g ae ha }\end{array}$} & \multirow{2}{*}{$\begin{array}{l}\text { Tomato } \\
\text { lines }\end{array}$} & \multicolumn{2}{|c|}{$1 \mathrm{DAT}^{\mathrm{a}}$} & \multicolumn{2}{|l|}{$3 \mathrm{DAT}$} & \multicolumn{2}{|c|}{$7 \mathrm{DAT}$} \\
\hline & & Leaves & Roots & Leaves & Roots & Leaves & Roots \\
\hline \multirow[t]{4}{*}{0} & TOM199 & $\begin{array}{l}0.0 \\
( \pm 0.0)^{b} b^{c}\end{array}$ & $\begin{array}{l}0.0 \\
( \pm 0.0) \mathrm{a}\end{array}$ & $\begin{array}{l}0.0 \\
( \pm 0.0) \mathrm{b}\end{array}$ & $\begin{array}{l}0.0 \\
( \pm 0.0) \mathrm{a}\end{array}$ & $\begin{array}{l}0.0 \\
( \pm 0.0) \mathrm{b}\end{array}$ & $\begin{array}{l}0.0 \\
( \pm 0.0) \mathrm{a}\end{array}$ \\
\hline & & 0.0 & 0.0 & 0.0 & 0.0 & 0.0 & 0.0 \\
\hline & TOM198 & $( \pm 0.0) \mathrm{b}$ & $( \pm 0.0) \mathrm{a}$ & $( \pm 0.0) \mathrm{b}$ & $( \pm 0.0) \mathrm{a}$ & $( \pm 0.0) \mathrm{b}$ & $( \pm 0.0) \mathrm{a}$ \\
\hline & TOM300 & $\begin{array}{l}0.0 \\
( \pm 0.0) \mathrm{b}\end{array}$ & $\begin{array}{l}0.0 \\
( \pm 0.0) \mathrm{a}\end{array}$ & $\begin{array}{l}0.0 \\
( \pm 0.0) \mathrm{b}\end{array}$ & $\begin{array}{l}0.0 \\
( \pm 0.0) \mathrm{a}\end{array}$ & $\begin{array}{l}0.0 \\
( \pm 0.0) \mathrm{b}\end{array}$ & $\begin{array}{l}0.0 \\
( \pm 0.0) \mathrm{a}\end{array}$ \\
\hline
\end{tabular}




\begin{tabular}{|c|c|c|c|c|c|c|c|}
\hline & $\begin{array}{l}\text { Better } \\
\text { Boy }\end{array}$ & $\begin{array}{l}0.0 \\
( \pm 0.0) b\end{array}$ & $\begin{array}{l}0.0 \\
( \pm 0.0) a\end{array}$ & $\begin{array}{l}0.0 \\
( \pm 0.0) b\end{array}$ & $\begin{array}{l}0.0 \\
( \pm 0.0) a\end{array}$ & $\begin{array}{l}0.0 \\
( \pm 0.0) \mathrm{b}\end{array}$ & $\begin{array}{l}0.0 \\
( \pm 0.0) a\end{array}$ \\
\hline \multicolumn{8}{|l|}{70} \\
\hline & TOM199 & $\begin{array}{l}97.0 \\
( \pm 2.5) \mathrm{a}\end{array}$ & $\begin{array}{l}3.0 \\
( \pm 0.09) \mathrm{a}\end{array}$ & $\begin{array}{l}96.0 \\
( \pm 3.0) \mathrm{a}\end{array}$ & $\begin{array}{l}4.0 \\
( \pm 0.03) \mathrm{a}\end{array}$ & $\begin{array}{l}97.0 \\
( \pm 1.0) \mathrm{a}\end{array}$ & $\begin{array}{l}3.0 \\
( \pm 0.06) a\end{array}$ \\
\hline & TOM198 & $\begin{array}{l}96.0 \\
( \pm 1.6) \mathrm{a}\end{array}$ & $\begin{array}{l}4.0 \\
( \pm 0.04) \mathrm{a}\end{array}$ & $\begin{array}{l}98.0 \\
( \pm 2.3) \mathrm{a}\end{array}$ & $\begin{array}{l}2.0 \\
( \pm 0.05) \mathrm{a}\end{array}$ & $\begin{array}{l}96.0 \\
( \pm 1.4) \mathrm{a}\end{array}$ & $\begin{array}{l}4.0 \\
( \pm 0.03) \mathrm{a}\end{array}$ \\
\hline & TOM300 & $\begin{array}{l}98.0 \\
( \pm 2.0) \mathrm{a}\end{array}$ & $\begin{array}{l}2.0 \\
( \pm 0.07) \mathrm{a}\end{array}$ & $\begin{array}{l}97.0 \\
( \pm 1.7) \mathrm{a}\end{array}$ & $\begin{array}{l}3.0 \\
( \pm 0.04) a\end{array}$ & $\begin{array}{l}98.0 \\
( \pm 2.8) \mathrm{a}\end{array}$ & $\begin{array}{l}2.0 \\
( \pm 0.05) \mathrm{a}\end{array}$ \\
\hline & Better & 97.0 & 3.0 & 98.0 & 2.0 & 95.0 & 5.0 \\
\hline & Boy & $( \pm 1.8) \mathrm{a}$ & $( \pm 0.05) \mathrm{a}$ & $( \pm 2.2) \mathrm{a}$ & $( \pm 0.06) \mathrm{a}$ & $( \pm 3.3) \mathrm{a}$ & $( \pm 0.04) \mathrm{a}$ \\
\hline & TOM199 & $\begin{array}{l}97.0 \\
( \pm 1.0) \mathrm{a}\end{array}$ & $\begin{array}{l}3.0 \\
( \pm 0.06) \mathrm{a}\end{array}$ & $\begin{array}{l}97.0 \\
( \pm 2.0) \mathrm{a}\end{array}$ & $\begin{array}{l}3.0 \\
( \pm 0.05) \mathrm{a}\end{array}$ & $\begin{array}{l}96.0 \\
( \pm 1.0) \mathrm{a}\end{array}$ & $\begin{array}{l}4.0 \\
( \pm 0.03) a\end{array}$ \\
\hline & TOM198 & $\begin{array}{l}97.0 \\
( \pm 1.2) \mathrm{a}\end{array}$ & $\begin{array}{l}3.0 \\
( \pm 0.07) \mathrm{a}\end{array}$ & $\begin{array}{l}97.0 \\
( \pm 3.0) \mathrm{a}\end{array}$ & $\begin{array}{l}3.0 \\
( \pm 0.04) \mathrm{a}\end{array}$ & $\begin{array}{l}96.0 \\
( \pm 1.9) \mathrm{a}\end{array}$ & $\begin{array}{l}4.0 \\
( \pm 0.04) \mathrm{a}\end{array}$ \\
\hline & TOM300 & $\begin{array}{l}97.0 \\
( \pm 1.7) \mathrm{a}\end{array}$ & $\begin{array}{l}3.0 \\
( \pm 0.04) \mathrm{a}\end{array}$ & $\begin{array}{l}96.0 \\
( \pm 1.4) \mathrm{a}\end{array}$ & $\begin{array}{l}4.0 \\
( \pm 0.02) \mathrm{a}\end{array}$ & $\begin{array}{l}98.0 \\
( \pm 2.1) \mathrm{a}\end{array}$ & $\begin{array}{l}2.0 \\
( \pm 0.07) \mathrm{a}\end{array}$ \\
\hline & Better & 98.0 & 2.0 & 98.0 & 2.0 & 97.0 & 3.0 \\
\hline & Boy & $( \pm 1.5) \mathrm{a}$ & $( \pm 0.06) \mathrm{a}$ & $( \pm 3.5) \mathrm{a}$ & $( \pm 0.02) \mathrm{a}$ & $( \pm 2.7) a$ & $( \pm 0.05) \mathrm{a}$ \\
\hline \multicolumn{8}{|l|}{210} \\
\hline & TOM199 & $\begin{array}{l}96.0 \\
( \pm 1.2) \mathrm{a}\end{array}$ & $\begin{array}{l}4.0 \\
( \pm 0.07) \mathrm{a}\end{array}$ & $\begin{array}{l}98.0 \\
( \pm 2.3) \mathrm{a}\end{array}$ & $\begin{array}{l}2.0 \\
( \pm 0.05) \mathrm{a}\end{array}$ & $\begin{array}{l}97.0 \\
( \pm 1.5) a\end{array}$ & $\begin{array}{l}3.0 \\
( \pm 0.04) \mathrm{a}\end{array}$ \\
\hline & TOM198 & $\begin{array}{l}95.0 \\
( \pm 2.0) \mathrm{a}\end{array}$ & $\begin{array}{l}5.0 \\
( \pm 0.03) \mathrm{a}\end{array}$ & $\begin{array}{l}97.0 \\
( \pm 1.0) \mathrm{a}\end{array}$ & $\begin{array}{l}3.0 \\
( \pm 0.08) \mathrm{a}\end{array}$ & $\begin{array}{l}96.0 \\
( \pm 1.0) \mathrm{a}\end{array}$ & $\begin{array}{l}4.0 \\
( \pm 0.09) \mathrm{a}\end{array}$ \\
\hline & TOM300 & $\begin{array}{l}97.0 \\
( \pm 1.8) \mathrm{a}\end{array}$ & $\begin{array}{l}3.0 \\
( \pm 0.04) \mathrm{a}\end{array}$ & $\begin{array}{l}98.0 \\
( \pm 1.3) \mathrm{a}\end{array}$ & $\begin{array}{l}2.0 \\
( \pm 0.06) a\end{array}$ & $\begin{array}{l}95.0 \\
( \pm 2.0) \mathrm{a}\end{array}$ & $\begin{array}{l}5.0 \\
( \pm 0.06) \mathrm{a}\end{array}$ \\
\hline & Better & 96.0 & 4.0 & 96.0 & 4.0 & 97.0 & 3.0 \\
\hline & Boy & $( \pm 2.5) \mathrm{a}$ & $( \pm 0.05) \mathrm{a}$ & $( \pm 1.5) \mathrm{a}$ & $( \pm 0.09) \mathrm{a}$ & $( \pm 1.1) \mathrm{a}$ & $( \pm 0.08) \mathrm{a}$ \\
\hline \multicolumn{8}{|l|}{280} \\
\hline & TOM199 & $\begin{array}{l}98.0 \\
( \pm 2.8) \mathrm{a}\end{array}$ & $\begin{array}{l}2.0 \\
( \pm 0.03) \mathrm{a}\end{array}$ & $\begin{array}{l}96.0 \\
( \pm 1.0) a\end{array}$ & $\begin{array}{l}4.0 \\
( \pm 0.08) a\end{array}$ & $\begin{array}{l}97.0 \\
( \pm 2.2) \mathrm{a}\end{array}$ & $\begin{array}{l}3.0 \\
( \pm 0.05) a\end{array}$ \\
\hline & TOM198 & 97.0 & 3.0 & 97.0 & 3.0 & 95.0 & 5.0 \\
\hline & IU⿴囗198 & $( \pm 2.6) \mathrm{a}$ & $( \pm 0.07) \mathrm{a}$ & $( \pm 3.2) \mathrm{a}$ & $( \pm 0.06) \mathrm{a}$ & $( \pm 2.3) \mathrm{a}$ & $( \pm 0.09) \mathrm{a}$ \\
\hline & TOM300 & 96.0 & 4.0 & 95.0 & 5.0 & 98.0 & 2.0 \\
\hline & IUIVISU0 & $( \pm 3.0) \mathrm{a}$ & $( \pm 0.05) \mathrm{a}$ & $( \pm 1.1) \mathrm{a}$ & $( \pm 0.04) \mathrm{a}$ & $( \pm 2.0) \mathrm{a}$ & $( \pm 0.06) \mathrm{a}$ \\
\hline & Better & 98.0 & 2.0 & 97.0 & 3.0 & 98.0 & 2.0 \\
\hline & Boy & $( \pm 1.6) \mathrm{a}$ & $( \pm 0.02) \mathrm{a}$ & $( \pm 2.7) \mathrm{a}$ & $( \pm 0.08) a$ & $( \pm 1.9) \mathrm{a}$ & $( \pm 0.04) \mathrm{a}$ \\
\hline
\end{tabular}

${ }^{a}$ Abbreviation: DAT, days after treatment.

${ }^{\mathrm{b}}$ Standard error.

${ }^{\mathrm{c}}$ Means within columns followed by the different letter are significantly different at $\mathrm{P} \leq 0.05$ using LSD's test. 
Based on the literature, the basis of differential response to dicamba between the wild accessions and the cultivar may be due to the difference in how they uptake, translocate, and metabolize the herbicide or changes caused in the structure of the herbicide's target protein (Zagnitko et al. 2001; Lovelace et al. 2007a; Beckie and Tardif 2012; Délye 2013; Alebrahim et al. 2017; Zangoueinejad et al. 2020b). In accordance with our results, dicamba tolerance in wheat (Triticum aestivum var. Gaines) and bluegrass (Poa pratensis var. Newport) plants was associated with herbicide metabolism (Broadhurst et al. 1966). Additionally, Chang and Born (1971) concluded that the primary reason for resistance to dicamba in wheat, barley (Hordeum vulgare L.), wild mustard (Sinapis arvensis L.), and tartary buckwheat [Fagopyrum tataricum (L.) Gaertn] was the selective uptake, translocation, and metabolism of dicamba. It was reported that broadleaf signalgrass [Urochloa platyphylla (Nash) R.D. Webster] is sensitive to nicosulfuron and resistant to primisulfuronb (Gallaher et al. 1999). U. platyphylla absorbed $20 \%$ more nicosulfuron than primisulfuron at 72 HAT (Gallaher et al. 1999). Differences in the sensitivity of common lambsquarters (Chenopodium album L.), giant foxtail (Setaria faberi L.), velvetleaf (Abutilon theophrasti L.), and E. crus-galli to glufosinate at the dose of $140 \mathrm{~g} \mathrm{ha}^{-1}$ was also found to be due to their differences in herbicide absorption and translocation (Steckel et al. 1997).

\section{Conclusion}

Based on the results, the wild tomato accessions were only tolerant to dicamba application at the rate of $70 \mathrm{~g}_{\text {ae }} \mathrm{ha}^{-1}$; however, they showed lower dicamba absorption than Better Boy at all dicamba doses. This suggests that the herbicide levels absorbed were enough to disrupt and finally block the growth processes of wild accessions at the dicamba application rates of 140, 210, and $240 \mathrm{~g}$ ae ha ${ }^{-1}$, while it was not sufficient to interrupt the growth processes in wild tomato accessions at the rate of $70 \mathrm{~g}_{\text {ae ha }}{ }^{-1}$. Also, the $\mathrm{H}_{2} \mathrm{O}_{2}$ content in wild accessions was lower than the Better Boy cultivar at $7 \mathrm{DAT}$ at the dicamba dose of $70 \mathrm{~g}$ ae ha ${ }^{-1}$. Since the production of $\mathrm{H}_{2} \mathrm{O}_{2}$ is associated with auxin herbicide activity, the decrease in the levels of $\mathrm{H}_{2} \mathrm{O}_{2}$ suggests a decline in dicamba activity over time in the wild accessions. Additionally, results revealed that the herbicide distribution pattern was not different between wild accessions and the commercial cultivar. Therefore, the basis of the tolerance observed in wild accessions compared to that in Better Boy may be due to differential dicamba absorption at the dose of $70 \mathrm{~g}$ ae $\mathrm{ha}^{-1}$. There is no doubt that 
seeking tomatoes with a high ability to tolerate drift rates of dicamba is an enthusiastic approach to develop dicamba-tolerant tomato commercial cultivars in the near future; our study presents the first step in this effort.

Author Contributions: Conceptualization, T.M.T. and R.Z.; Investigation, R.Z., E.B.C., Z.Y. and T.M.T.; Resources, T.M.T., R.Z., and R.G.S.; Writing - Original Draft Preparation, R.Z., T.M.T., and M.T.A.; Writing - Review \& Editing, R.Z., T.M.T., S.S., Z.Y., E.B.C., R.G.S., and M.T.A.; Visualization, R.Z. and T.M.T.; Funding Acquisition, T.M.T and R.G.S.

Funding: Funding for this project was provided by Specialty Crop Block Grant sponsored by the Mississippi Department of Agriculture and Commerce/U.S. Department of AgricultureAgriculture Marketing Service, and is based upon work supported by the National Institute of Food and Agriculture, U.S. Department of Agriculture, Hatch project under accession number 230100 .

\section{Institutional Review Board Statement:}

\section{Informed Consent Statement:}

\section{Data Availability Statement}

The data that support the findings of this study are openly available in "figshare" at https://doi.org/10.6084/m9.figshare.14428970.v1.

Conflicts of Interest: The authors declare no conflict of interest.

\section{References}

Alebrahim MT, Zangoueinejad R, Tseng TM. 2017. Biochemical and Molecular Knowledge about Developing Herbicide-Resistant Weeds. In: Pacanoski Z, editors. Herbicide Resistance in Weeds and Crops. London: IntechOpen; p. 101-131.

Beckie HJ, Tardif FJ. 2012. Herbicide cross resistance in weeds. Crop Prot. 35: 15-28. 
Broadhurst NA, Montgomery ML, Freed VH. 1966. Metabolism of 2-methoxy-3, 6dichlorobenzoic acid (dicamba) by wheat and bluegrass plants. J Agric Food Chem. 14(6): $585-588$.

Chang FY, Born WV. 1971. Dicamba uptake, translocation, metabolism, and selectivity. Weed Sci. 19(1): 113-117.

Colquhoun JB, Heider DJ, Rittmeyer RA. 2014. Relationship between visual injury from synthetic auxin and glyphosate herbicides and snap bean and potato yield. Weed Technol. 28(4): 671-678.

Délye C. 2013. Unravelling the genetic bases of non-target-site-based resistance (NTSR) to herbicides: a major challenge for weed science in the forthcoming decade. Pest Manag Sci. 69(2): 176-187.

Fagliari JR, Oliveira Jr RSD, Constantin J. 2005. Impact of sublethal doses of 2, 4-D, simulating drift, on tomato yield. J Environ Sci Heal B. 40(1): 201-206.

Frans R, Talbert R, Marx D, Crowley H. 1986. Experimental Design and Techniques for Measuring and Analyzing Plant Responses to Weed Control Practices. In: Camper ND, editor. Southern Weed Science Society, Research Methods in Weed Science. 3rd Edition. WSSA, Champaign, p. 29-46.

Gallaher K, Mueller TC, Hayes RM, Schwartz O, Barrett M. 1999. Absorption, translocation, and metabolism of primisulfuron and nicosulfuron in broadleaf signalgrass (Brachiaria platyphylla) and corn. Weed Sci. 8-12.

Gilreath JP, Chase CA, Locascio SJ. 2001. Crop injury from sublethal rates of herbicide. I. Tomato. HortScience. 36(4): 669-673.

Greenham CG. 1962. Studies on translocation of herbicides in skeleton weed (Chondrilla juncea L.). Aust J Agric Res. 13(4): 624-637.

Greenham CG. 1973. Investigations on skeleton weed (Chondrilla juncea L.) with picloram and 2, 4-D. Weed Res. 13(3): 243-253. 
Grossmann K. 1998. Quinclorac belongs to a new class of highly selective auxin herbicides. Weed Sci. 707-716.

Grossmann K. 2009. Auxin herbicides: current status of mechanism and mode of action. Pest Manag Sci. 66(2): 113-120.

Guilbault GG, Kramer DN, Hackley EB. 1967. New substrate for fluorometric determination of oxidative enzymes. Int J Anal Chem. 39(2):271-271.

Hatterman-Valenti H, Endres G, Jenks B, Ostlie M, Reinhardt T, Robinson A, Stenger J, Zollinger R. 2017. Defining glyphosate and dicamba drift injury to dry edible pea, dry edible bean, and potato. HortTechnology. 27(4): 502-509.

Hermes, M. E. (2020). Effects of Simulated 2, 4-D and Dicamba Drift on Field-Grown Tomato Plants (Doctoral dissertation).

Heuvelink E, Okello RCO. 2005. Developmental processes. In: Heuvelink E, editor. Tomatoes. Wallingford: CABI Publishing; p. 53-83.

Ivanchenko MG, Den Os D, Monshausen GB, Dubrovsky JG, Bednářová A, Krishnan N. 2013. Auxin increases the hydrogen peroxide $\left(\mathrm{H}_{2} \mathrm{O}_{2}\right)$ concentration in tomato (Solanum lycopersicum) root tips while inhibiting root growth. Ann Bot. 112(6): 1107-1116.

Knezevic, S. Z., Osipitan, O. A., \& Scott, J. E. (2018). Sensitivity of grape and tomato to microrates of dicamba-based herbicides. $J$ Hort, 5(1).

Kohler EA, Throssell CS, Reicher ZJ. 2004. 2,4-D rate response, absorption, and translocation of two ground ivy (Glechoma hederacea) populations. Weed Technol. 18(4): 917-923.

Kruger GR, Johnson WG, Doohan DJ, Weller SC. 2012. Dose response of glyphosate and dicamba on tomato (Lycopersicon esculentum) injury. Weed Technol. 26(2): 256-260.

Lovelace ML, Talbert RE, Hoagland RE, Scherder EF. 2007a. Quinclorac absorption and translocation characteristics in quinclorac-and propanil-resistant and-susceptible barnyardgrass (Echinochloa crus-galli) biotypes. Weed Technol. 21(3): 683-687. 
Lovelace ML, Talbert RE, Scherder EF, Hoagland RE. 2007b. Effects of multiple applications of simulated quinclorac drift rates on tomato. Weed Sci. 55(2): 169-177.

Mithila J, Hall JC, Johnson WG, Kelley KB, Riechers DE. 2011. Evolution of resistance to auxinic herbicides: historical perspectives, mechanisms of resistance, and implications for broadleaf weed management in agronomic crops. Weed Sci. 59(4): 445-457.

Mohseni-Moghadam M, Doohan D. 2015. Response of bell pepper and broccoli to simulated drift rates of 2, 4-D and dicamba. Weed Technol. 29(2): 226-232.

Romero-Puertas MC, McCarthy I, Gómez M, Sandalio LM, Corpas FJ, Del Rio LA, Palma JM. 2004. Reactive oxygen species-mediated enzymatic systems involved in the oxidative action of 2, 4-dichlorophenoxyacetic acid. Plant Cell Environ. 27(9): 1135-1148.

Schmoll JT, Harrison SK, Regnier EE, Bennett MA. 2000. Hydroponic Tomato (Lycopersicon esculentum) Response to Dicamba in the Nutrient Media 1. Weed Technol. 14(3): 562-568.

Shin EH, Choi JH, Abd El-Aty AM, Khay S, Kim SJ, Im MH, Kwon CH, Shim JH. 2011. Simultaneous determination of three acidic herbicide residues in food crops using HPLC and confirmation via LC-MS/MS. Biomed Chromatogr. 25(1-2): 124-135.

Steckel GJ, Hart SE, Wax LM. 1997. Absorption and translocation of glufosinate on four weed species. Weed Sci. 45(3): 378-381.

Walsh TA, Neal R, Merlo AO, Honma M, Hicks GR, Wolff K, Matsumura W, Davies JP. 2006. Mutations in an auxin receptor homolog AFB5 and in SGT1b confer resistance to synthetic picolinate auxins and not to 2,4-dichlorophenoxyacetic acid or indole-3-acetic acid in Arabidopsis. Plant Physiol. 142(2): 542-552.

Zagnitko O, Jelenska J, Tevzadze G, Haselkorn R, Gornicki P. 2001. An isoleucine/leucine residue in the carboxyltransferase domain of acetyl-CoA carboxylase is critical for interaction with aryloxyphenoxypropionate and cyclohexanedione inhibitors. Proc Natl Acad Sci USA. 98(12): 6617-6622.

Zangoueinejad R, Alebrahim MT, Tseng TM. 2019. Evaluation of auxin tolerance in selected tomato germplasm under greenhouse and field conditions. Weed Technol. 33(6): 815-822. 
Zangoueinejad R, Alebrahim MT, Tseng TM. 2020a. Absorption and Translocation of Dicamba in Dicamba-Tolerant Wild Tomato. Can J Plant Sci. https://doi.org/10.1139/CJPS-2019$\underline{0314}$

Zangoueinejad R, Alebrahim MT, Tseng TM. 2020b. Molecular and Physiological Response to Dicamba in Dicamba-Tolerant Wild Tomato. J Miss Acad Sci. 65(3): 358-373.

Zangoueinejad R. 2019. Study the mechanism(s) of tolerance to herbicides in selected tomato lines [dissertation]. Ardabil, Iran: University of Mohaghegh Ardabili. Persian.

Zheng HG, Hall JC. 2001. Understanding auxinic herbicide resistance in wild mustard: physiological, biochemical, and molecular genetic approaches. Weed Sci. 49(2): 276-281. 